\title{
The impact of the container size and soil preparation on afforestation success of one year old holm oak (Quercus ilex) seedlings in Croatian Mediterranean area
}

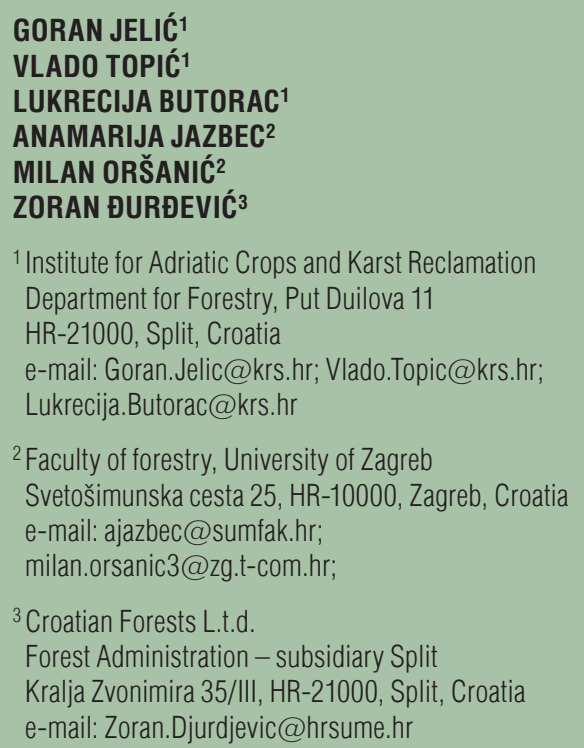

Correspondence:

Goran Jelić

E-mail:

Goran.Jelic@krs.hr

Key words: Mediterranean karst area, container type, morphological features of seedlings, soil preparation, afforestation success, height increment
Received July 22, 2015.

Revised November 13, 2015.

Accepted January 19, 2016.

\begin{abstract}
:
Background and Purpose: Morphological features of one year old holm oak (Quercus ilex) seedlings grown in different types of containers were analyzed in order to establish the effect of container type on seedlings' development. The survival rates and the development of the seedlings were measured and monitored in the period of six years, on an experimental plot with the aim to assess the influence of container size and soil preparation on afforestation success in Mediterranean karst area.
\end{abstract}

Materials and Methods: Four types of containers were used: $M P_{53 / 12}$, $M P_{33118}, T_{7124}$ and $T_{8124}$. Morphological features of seedlings include: height, root collar diameter, biomass of the aboveground part, root biomass and total biomass. Two morphological indexes were calculated from the measured variables: S:R ratio and DQI. Morphological dimensions of root systems are, namely: total length, the number of tips, surface area and volume. Seedlings were arranged over the area of the experimental plot according to the randomized block method. Within each block $(0,2 \mathrm{ha})$ two types of soil preparation prior to planting were performed: in pits with dimensions of $40 \times 40 \times 40 \mathrm{~cm}$, and on the ripping ground. Each year during the experiment, seedlings were measured for height increment and survival rates (e.g. mortality), with respect to the container type and the planting method.

Results: Almost all morphological features of seedlings have significantly higher values in larger containers $\left(T_{7 / 24}\right.$ and $\left.T_{8 / 24}\right)$ compared to smaller containers $\left(M P_{53 / 12}\right.$ and $\left.M P_{33 / 18}\right)$. Survival rates over six years in field experiment are influenced mainly by container size in interaction with soil preparation method $(\exp (\beta)=6.5789 ; p<0.0001)$. The container size exhibited influence on height increment of holm oak during first six years ( $F=20.619, p=0.000012)$.

Conclusions: Soil preparation by ripping combined with high-quality seedlings played the most important role in the holm oak's survival in the research area.

\section{INTRODUCTION}

$T$ he container size is commonly described through its volume, height 1 (depth) and diameter. The volume of a container dictates the size of the seedling that grows in it. Several authors investigated the influence of the container size on the seedlings development of the trees used for afforestation in the Mediterranean area $(5,6,7,9,23,24$, and 25). Container depth is one of the most important characteristics which influence the seedlings' morphology, because it directly affects the ca- 
pacity to hold moisture and the root's ability to bind air (10). The depth of the container determines the growth of the root system and the tap root length, thus the morpho-functional characteristics and the quality of seedlings, expressed with Dickson's quality index (DQI), are improved by using deeper containers (3). The result is a greater transportation capacity in the root system, which leads to higher water content in the plant during the stressful drought period. Low-quality seedlings showed weaker morphological and physiological characteristics that reduce their chances of survival and development in a field experiment under stressful conditions (14). One of the most important factors, which directly affects the afforestation success, is soil preparation for afforestation. Soil preparation for afforestation creates favorable conditions for growth and development of a young plant by changing its structure, thus changing the nutrients and water availability for a young plant (20). Soil preparation creates favorable water-air relations in soil that enable optimal biochemical processes necessary for plant's establishment. Soil preparation improves the soil structure; its properties are changed in the short term by increasing the usable volume of soil, the infiltration rate and the water retention capacity (2). Generally, nursery researchers investigate nursery treatments and silviculturalists investigate site preparation methods. Due to this fragmented approach, trials that combine nursery treatments with site preparation treatments are rare. As a result, much more is known about the main effects, than it is known about their interactions (19). Considering the insufficient research on this issue and the importance that it has from the scientific and economic point of view, the aim of this research was to investigate the impact of container size on morphological characteristics of the holm oak (Quercus ilex L.) one year old seedlings and the influence of the container size and soil preparation on their growth and development.

\section{MATERIALS AND METHODS}

\section{Research in the nursery}

The seeds used for the production of holm oak seedlings were collected in the seed stands within the Management unit "Biograd" managed by the forest office Biograd, Forest Administration of Split. The seeds of holm oak were sown in four container types (Table 1), respectively, two types of classic reusable containers (Multipot 53/12 - $\mathrm{MP}_{53 / 12}$ and Multipot 33/18 - $\mathrm{MP}_{33 / 18}$ ) and two types of polyethylene cones for single use (Polyethylene cone $7 / 24-T_{7 / 24}$ and Polyethylene cone 8/24- $T_{8 / 24}$. The sowing of seeds in the nursery was done manually, during March and April 2002. The seedlings of holm oak were cultivated as one-year-olds $(1+0)$. As a substrate for the production of plants in containers, the mixture of peat and soil in the ratio 2: 1 was used with addition of $5 \mathrm{~kg}$ $\operatorname{NPK}(7: 14: 21)$ fertilizer per $1 \mathrm{~m}^{3}$.

\section{Laboratory research}

For measuring and laboratory analysis of seedlings' morphological parameters, 20 sample seedlings of holm oak for each container type were randomly selected. Studied seedling variables (morphological features) include: seedling height, root collar diameter, biomass of the aboveground part of the seedlings, root biomass and total seedling biomass. Two morphological indexes were calculated from measured variables: the $S: R$ ratio (shoot/ root) and DQI (Dickson's Quality Index):

$$
\text { 1. Dickson's Quality Index (DQI) }=\frac{T S D W(\mathrm{~g})}{\frac{H(\mathrm{~cm})}{D(\mathrm{~mm})}+\frac{S W(\mathrm{~g})}{R W(\mathrm{~g})}}
$$

TSDW - Total seedling dry weight

$$
\begin{array}{ll}
\text { H } & \text { - Height } \\
\text { D } & \text { - Diameter } \\
\text { SW } & \text { - Stem weight (dry) } \\
\text { RW } & \text { - Root weight (dry) }
\end{array}
$$

2. Shoot/root ratio $(\mathrm{S}: \mathrm{R})=\frac{S W(\mathrm{~g})}{R W(\mathrm{~g})}$

The root's morphological parameters' measurement was performed with WinRhizo 2005a software (Regent Instruments, Quebec City, Quebec, Canada). Prior to scanning, the root samples were cleaned from the substrate and placed in a plexiglass vessel $(200 \times 300 \mathrm{~mm})$ filled with water, in order to minimize the overlapping during the scan. Then the samples were dried in a drying oven for 48 hours at a temperature of $70^{\circ} \mathrm{C}$. After drying, above ground and underground parts of the samples were weighted.

\section{Research on the experimental site}

The experimental object where afforestation was performed is situated (Figure 1) in the Mediterranean part of Croatia $(9 \mathrm{~km}$ southeast of Šibenik and $4.5 \mathrm{~km}$ from the coast). Object's coordinates are $43^{\circ} 41^{\prime} 37^{\prime \prime} \mathrm{N} ; 16^{\circ} 01^{\prime} 01^{\prime \prime}$ E. It is located at an altitude of 150-156 m above sea level, with southern exposure and slope $5-10^{\circ}$. The experimental object is represented by brown soil on limestone and dolomite. According to Lang's rain factor and the Köppen climate classification, the characteristics of this climate zone, where our research was conducted is semi-arid Mediterranean climate with average annual air temperature of $15.4^{\circ} \mathrm{C}$. The average annual rainfall is $778.6 \mathrm{~mm}$. A total of 775 oak seedlings were planted in three separated blocks (3 repetitions), distributed over the experimental object according to randomized block method. Each block has an area of 0.2 hectares $(40 \times 50 \mathrm{~m})$ and it is divided longitudinally into 2 sub blocks $(2 \times 0.1 \mathrm{ha})$. Within each block, two types of soil preparation prior to planting were performed: planting in pits with dimensions of $40 \times 40 \times 40 \mathrm{~cm}$ without prior ripping and on the 


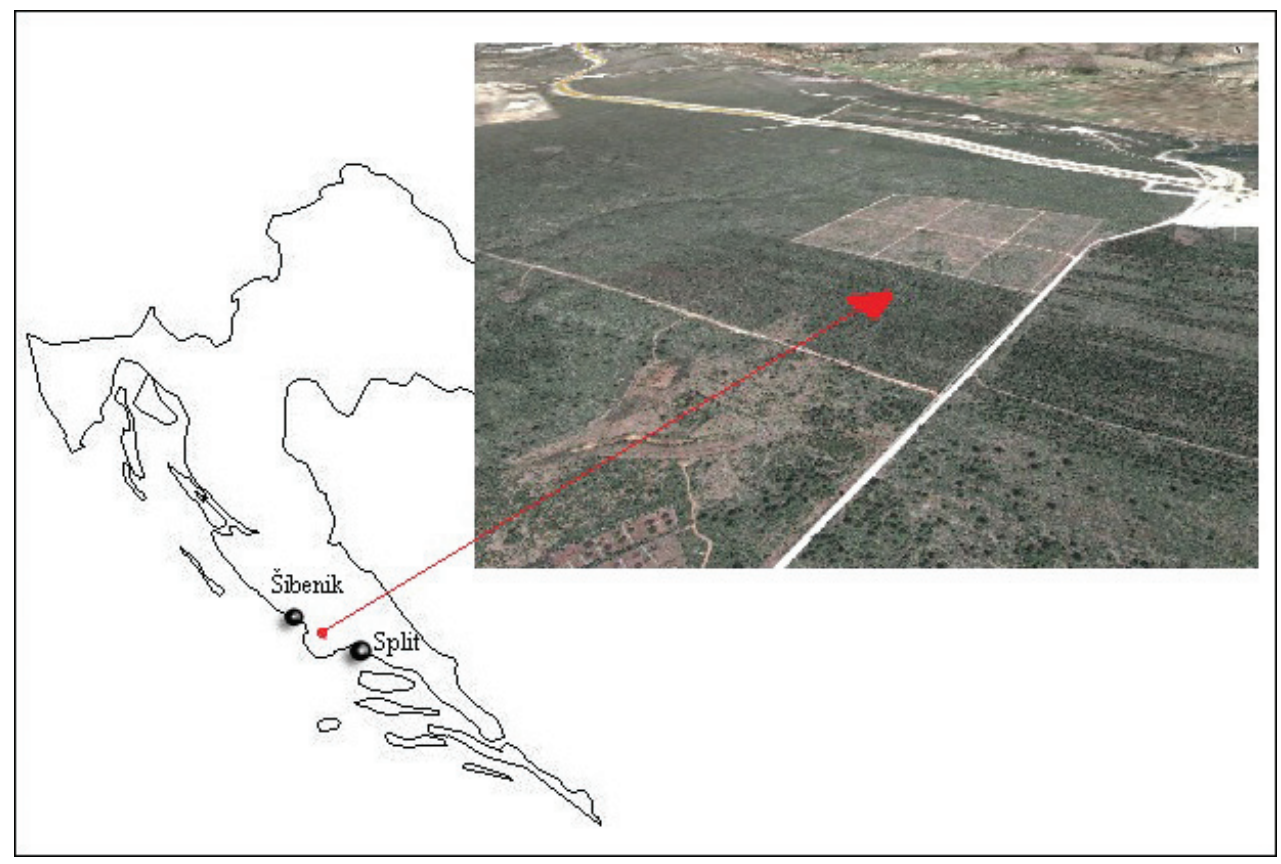

Figure 1 Experimental plot (www.earth.google.com)

ripped ground. For the purposes of this article, the term "soil preparation" includes only mechanical subsoiling (ripping). Each year during the experiment, after the growing season, seedlings were measured for height increment and survival rates (e.g. mortality), with respect to the container type and the planting method.

\section{The processing and the analysis of data}

For all analyzed variables, a part of the descriptive statistics was made (mean and standard deviation). For statistical analysis the significance level of $p=0.05$ was considered statistically significant. Morphological features with regard to container type were evaluated with the analysis of variance (ANOVA) and multiple Tukey's post hoc test. The relationships between survival rates in 2009 and initial seedling height, container type, soil preparation method, as well as their interactions, for the period between 2003 and 2009, were evaluated by logistic regression (18). The relations between height increment during six years and the container type, soil preparation method, as well as their interactions, were evaluated with the repeated measure analysis of variance (4). The analysis of variance and the variance analysis of repeated measures were made using statistical package STATISTICA 7.1 (28), while the logistic regression was made using statistical package SAS 8.1 (29).

\section{RESULTS AND DISCUSSION}

\section{The morphological features of one year old holm oak seedlings grown in different types of containers}

The morphological features of one year old holm oak seedlings, cultivated in larger containers $\left(\mathrm{T}_{7 / 24}\right.$ and $\left.\mathrm{T}_{8 / 24}\right)$ showed statistically significant (ANOVA and Tukey's post hoc) plants' height values in relation to the seedlings from containers $\mathrm{MP}_{53 / 12}$ and $\mathrm{MP}_{33 / 18}$ (Figure 2 and Table 2). Root collar diameters (RCD) of seedlings from the smaller containers - SC $\left(\mathrm{MP}_{53 / 12}\right.$ and $\left.\mathrm{MP}_{33 / 18}\right)$ were significantly different from RCD of seedlings cultivated in larger containers - $\mathrm{LC}\left(\mathrm{T}_{7 / 24}\right.$ and $\left.\mathrm{T}_{8 / 24}\right)$. The results also

Table 1. General features of the containers used in the experiment

\begin{tabular}{|c|c|c|c|c|c|c|}
\hline Container type & $\begin{array}{l}\text { Code } \\
\text { name }\end{array}$ & $\begin{array}{l}\text { Cross } \\
\text { section }\end{array}$ & $\begin{array}{l}\text { Volume of cell } \\
\qquad\left(\mathrm{cm}^{3}\right)\end{array}$ & $\begin{array}{l}\text { Depth } \\
(\mathrm{cm})\end{array}$ & $\begin{array}{l}\text { Diameter at the } \\
\text { top }(\mathrm{cm})\end{array}$ & $\begin{array}{l}\text { Plant density } \\
\left(\mathrm{N} / \mathrm{m}^{2}\right)\end{array}$ \\
\hline Multipot 53/12 & $\mathrm{MP}_{53 / 12}$ & Polyedric hexagon & 120 & 12 & 4 & 660 \\
\hline Multipot 33/18 & $\mathrm{MP}_{33 / 18}$ & Polyedric hexagon & 220 & 18 & 4,5 & 498 \\
\hline Polyethylene cone $7 / 24$ & $\mathrm{~T}_{7 / 24}$ & Round & 923 & 24 & 7 & 196 \\
\hline Polyethylene cone $8 / 24$ & $\mathrm{~T}_{7 / 24}$ & Round & 1205 & 24 & 8 & 156 \\
\hline
\end{tabular}




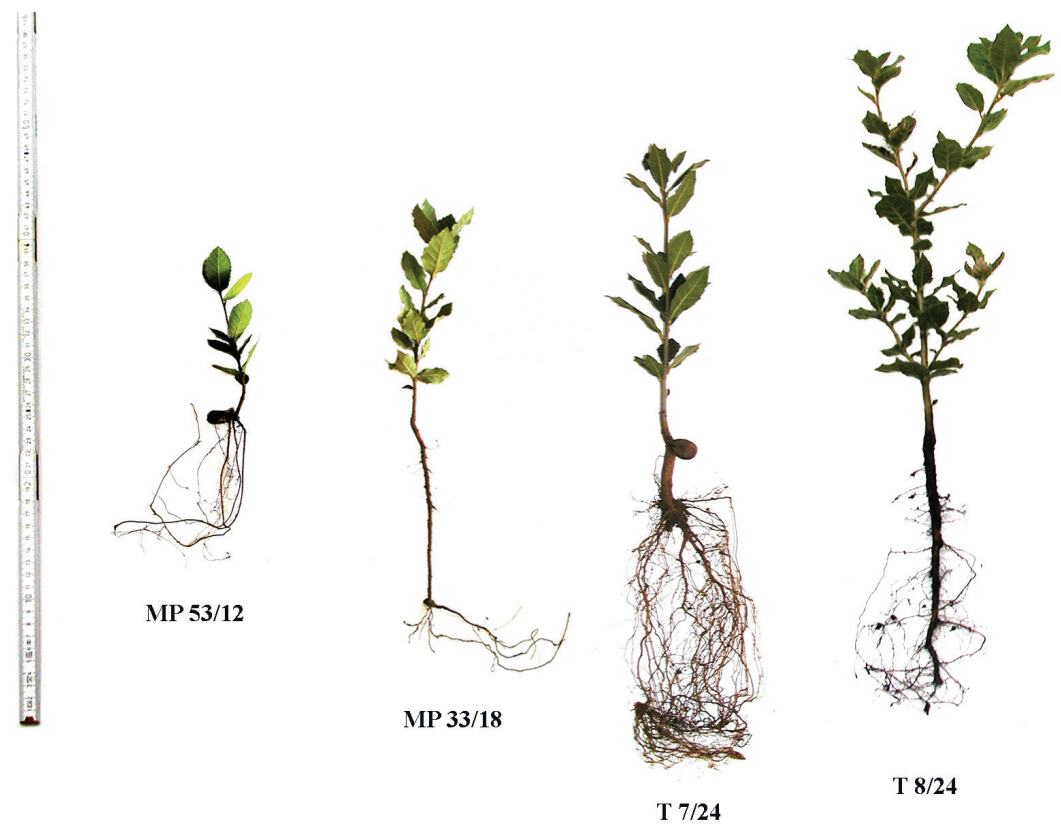

Quercus ilex L.

Figure 2 Average heights of one year old holm oak (Quercus ilex) seedlings in different container types

Table 2. Morphological characteristics, biomass and qualitative morphological indexes of one year old holm oak (Quercus ilex) seedlings from different container types and the results of one way ANOVA and Tukey's test. Numbers in a row followed by the same letter are not significantly different according to Tukey's test $(p=0.05)$

\begin{tabular}{|c|c|c|c|c|c|c|c|c|c|c|c|c|}
\hline & \multirow{3}{*}{ Variable } & \multicolumn{10}{|c|}{ Container type } & \multirow[b]{3}{*}{$\mathrm{p}$} \\
\hline & & \multicolumn{3}{|c|}{$\mathrm{MP}_{53 / 12}$} & \multicolumn{2}{|c|}{$\mathrm{MP}_{33 / 18}$} & \multicolumn{2}{|c|}{$\mathrm{T}_{7 / 24}$} & \multicolumn{2}{|c|}{$\mathrm{T}_{8 / 24}$} & \multirow[b]{2}{*}{$\mathrm{F}$} & \\
\hline & & $\mathrm{N}$ & Mean & S. D. & Mean & S. D. & Mean & S. D. & Mean & S. D. & & \\
\hline \multirow{6}{*}{ Root system } & Seedling height, $\mathrm{cm}$ & 20 & $11.69^{(\mathrm{a})}$ & 1.97 & $12.71^{(a)}$ & 1.97 & $18.56^{(\mathrm{b})}$ & 2.38 & $19.19^{(\mathrm{b})}$ & 1.45 & 77.80 & $<0.0001$ \\
\hline & Root collar diameter, $\mathrm{cm}$ & 20 & $3.13^{(\mathrm{a})}$ & 0.59 & $3.17^{(\mathrm{a})}$ & 0.50 & $4.71^{(\mathrm{b})}$ & 0.42 & $4.64^{(\mathrm{b})}$ & 0.36 & 68.42 & $<0.0001$ \\
\hline & Total lenght, $\mathrm{cm}$ & 20 & $153.68^{(\mathrm{a})}$ & 15.38 & $190.77^{(\mathrm{a})}$ & 48.18 & $382.12^{(\mathrm{b})}$ & 93.06 & $397.43^{(\mathrm{b})}$ & 84.16 & 70.14 & $<0.0001$ \\
\hline & Number of TIP's, piece & 20 & $396^{(a)}$ & 62.00 & $468^{(\mathrm{a})}$ & 76 & $1227^{(\mathrm{b})}$ & 467 & $1836^{(\mathrm{c})}$ & 646.0 & 58.18 & $<0.0001$ \\
\hline & Root volume, $\mathrm{cm}^{3}$ & 20 & $0.470^{(\mathrm{a})}$ & 0.077 & $0.562^{(\mathrm{b})}$ & 0.052 & $1.038^{(c)}$ & 0.127 & $1.051^{(\mathrm{c})}$ & 0.10 & 217.21 & $<0.0001$ \\
\hline & Surface area, $\mathrm{cm}^{2}$ & 20 & $33.02^{(a)}$ & 5.49 & $36.02^{(a)}$ & 4.11 & $71.56^{(\mathrm{b})}$ & 5.89 & $70.52^{(b)}$ & 6.21 & 296.75 & $<0.0001$ \\
\hline \multirow{3}{*}{ Biomass } & $\begin{array}{l}\text { Dry mass of above ground } \\
\text { part, } g\end{array}$ & 20 & $0.891^{(\mathrm{a})}$ & 0.179 & $1.015^{(\mathrm{a})}$ & 0.171 & $1.929^{(b)}$ & 1.110 & $1.977^{(\mathrm{b})}$ & 0.235 & 170.15 & $<0.0001$ \\
\hline & Dry mass of roots, $g$ & 20 & $0.475^{(\mathrm{a})}$ & 0.086 & $0.599^{(b)}$ & 0.065 & $1.153^{(\mathrm{c})}$ & 0.134 & $1.157^{(\mathrm{c})}$ & 0.098 & 265.73 & $<0.0001$ \\
\hline & Dry mass of plant, $g$ & 20 & $1.350^{(\mathrm{a})}$ & 0.235 & $1.614^{(\mathrm{b})}$ & 0.225 & $3.083^{(c)}$ & 0.315 & $3.133^{(c)}$ & 0.322 & 231.56 & $<0.0001$ \\
\hline \multirow{2}{*}{$\begin{array}{l}\text { Morphological } \\
\text { indexes }\end{array}$} & Biomass ratio: shoot/root & 20 & $1.89^{(\mathrm{a})}$ & 0.27 & $1.69^{(\mathrm{b})}$ & 0.19 & $1.69^{(\mathrm{b})}$ & 0.14 & $1.71^{(\mathrm{b})}$ & 0.11 & 5.30 & 0.0023 \\
\hline & $\begin{array}{l}\text { Dickson Quality Index } \\
\text { (DQI) }\end{array}$ & 20 & $0.24^{(\mathrm{a})}$ & 0.05 & $0.28^{(\mathrm{b})}$ & 0.04 & $0.55^{(\mathrm{c})}$ & 0.05 & $0.54^{(\mathrm{c})}$ & 0.05 & 217.18 & $<0.0001$ \\
\hline
\end{tabular}

showed that there is no statistical significance in the RCD size of the seedlings within two smaller and thus within the two larger containers. Analyzing only the results of seedling height and RCD, it could be concluded that it is almost the same if we cultivate the observed seedlings in container volume of either $120 \mathrm{~cm}^{3}$ or $220 \mathrm{~cm}^{3}$ for one year. According to EU regulations (30), all the plants reached the appropriate size for planting. According to these regulations, the height of one year old holm oak seedlings must be between 8 and $30 \mathrm{~cm}$, and RCD must be greater than $3 \mathrm{~mm}$. However, it should be taken into account that in the smallest containers $\left(120 \mathrm{~cm}^{3}\right)$, within 

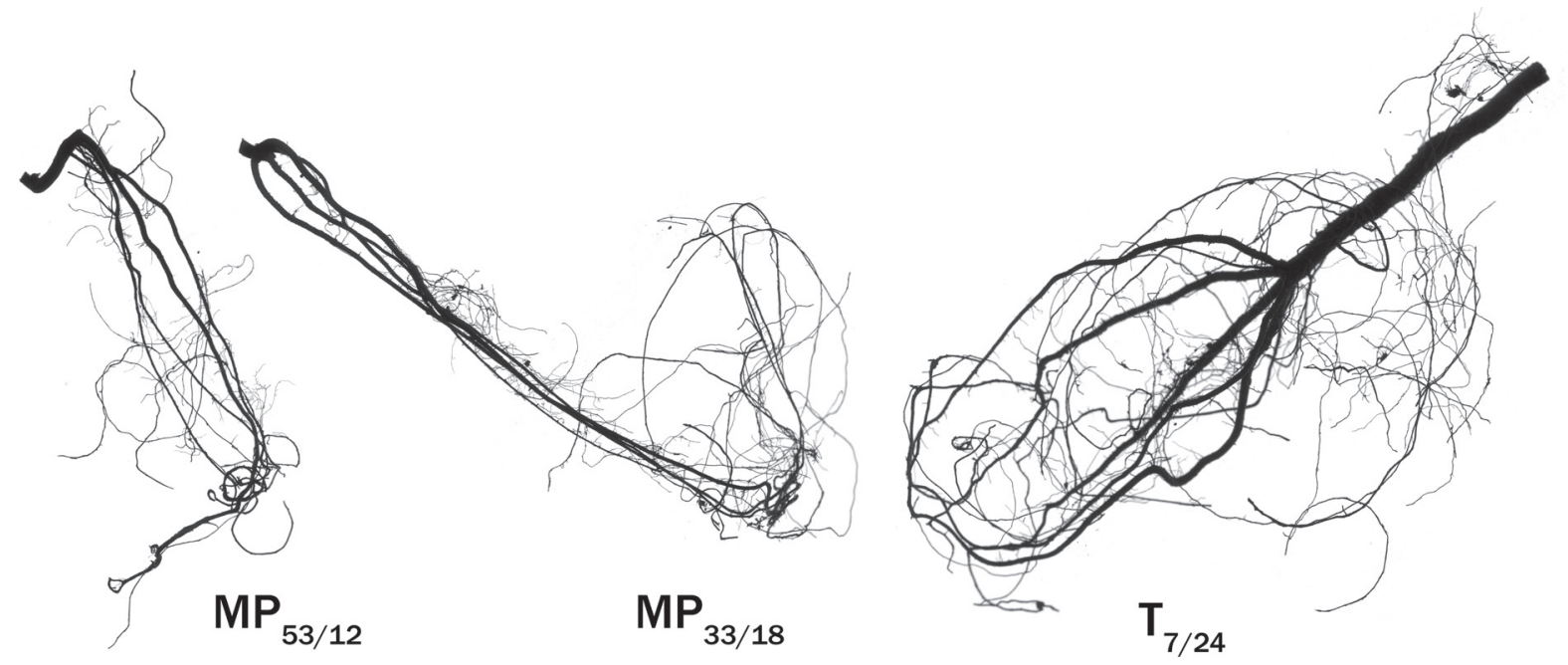

Figure 3. A comparison of root systems of one year old holm oak (Quercus ilex) seedlings from different container types $\left(M P_{53 / 12}, M P_{33 / 18}\right.$ and $T_{7 / 24}$ )

one year serious root deformations occurred (23). Visual observations done during the production of seedlings in the nursery established that one year old holm oak seedlings' root system has a simple architecture with a very strong and pointed tap root, which dominates by its length and thickness, and numerous very thin lateral roots, which can be very poor (Figure 3); this was also stated by Topić et al. (23) and Ocvirek (13) for pedunculate oak. The bind of roots of holm oak in container $\mathrm{MP}_{53 / 12}$ was very similar to the bind of roots in $\mathrm{MP}_{33 / 18}$ container, but in $\mathrm{MP}_{53 / 12}$ containers, the bind of roots naturally occurred earlier along with the deformations as a result of a smaller container volume. Circular and rebound growth of the root systems in containers $\mathrm{MP}_{53 / 12}$ and $\mathrm{MP}_{33 / 18}$ was also noticed. In containers $\mathrm{T}_{7 / 24}$ and $\mathrm{T}_{8 / 24}$ (larger containers) the root system was better developed compared to $\mathrm{MP}_{33 / 18}$, or especially to $\mathrm{MP}_{53 / 12}$ containers. The bind of roots of seedlings cultivated in larger containers was insufficient, although the roots were not deformed. Analyzing the root systems of holm oak seedlings, it was established that the root volume of seedlings cultivated in $\mathrm{MP}_{53 / 12}$ containers was significantly smaller in respect to the root volume of seedlings from other containers (Table 2 ). The tap root length of holm oak seedlings was determined by the depth of the container (16). Our previous research also shows that the largest proportion of root volume is allocated to the tap root. Chirino et al. (3) also determined much greater root volume by cultivating cork oak (Quercus suber L.) seedlings in containers with a greater depth. Seedlings with greater root volume have a higher water and nutrient intake compared to the seedlings with a smaller root volume, and it is one of the key factors in avoiding stress in the early stages after field transplantation, especially during the summer dry season (26). Consequently, it could be concluded that the root volume, with regard to the morphological aspect, can be an important indicator of the seedlings' quality. The root surface area of the seedling represents the absorption surface, by which root extracts water and minerals from the soil (21). Therefore, larger root surface means greater absorption capacity of roots and, consequently, higher seedling quality. Our results show a statistically significant difference in the root surface area, depending on the container size (Table 2), significantly in favor of the seedlings from larger volume containers. There were no differences in the root surface area between the seedlings cultivated in smaller containers, and there were also no statistically significant differences between the seedlings from larger containers. Total root length compared to the root surface area is a better absorption capacity indicator (8). The explanation for this statement the author finds in the slow water movement in the soil, while water as such is available to fine roots, which are more effective than coarse roots in water, and are especially effective in nutrient absorption. Fine roots (roots that have less than $0.5 \mathrm{~mm}$ in diameter), made the bulk of its total root length (approximately $90 \%$ of the total root length; data not shown in the article) on seedlings from all container types. Total root length was significantly influenced by the container size (Table 2). Similar results were also published by other authors $(9,23,24$, and 25). Seedlings with significantly denser roots were produced in larger containers. Seedlings from LC had triple or even more than fourfold larger number of root tips in relation to seedlings from SC (Table 2). Holm oak seedlings produced in LC an accumulated mass of aboveground part and a mass of roots, and thus the total biomass more than twofold compared to those produced in SC (Table2). Obtained results are significant indicators of the great impact that container size has on the morphological features of one year old holm oak seedlings. Dominguez Lerena et al. (6) had similar results for the stone pine (Pinus pinea L.), pointing 


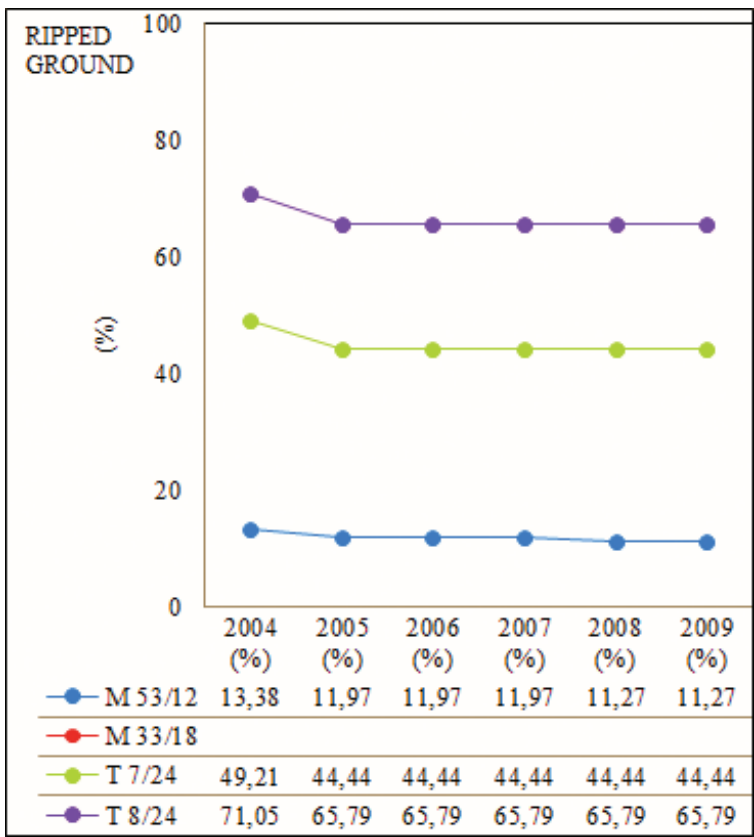

Figure 4 Holm oak's (Quercus ilex) survival after 6 years, planted in ripped ground, different container types

out that the seedlings from larger containers had significantly greater assimilation of $\mathrm{N}, \mathrm{P}, \mathrm{K}$, compared to the seedlings from smaller containers. This could be an explanation for the differences in size of the seedlings cultivated in different size of containers. The shoot : root ratio $(S: R)$ is a morphological feature, and the basis for the use of this feature comes from the perspective of the water balance: "a certain amount (surface area or dry mass) of transpiring foliage needs a certain amount (surface area or dry mass) of roots to absorb soil water and offset transpirational losses" (1). A low shoot: root ratio means that roots are abundant with respect to the foliage area and that the seedling has a high water stress avoidance potential (1). In this study, the container size had an impact on the weight of above ground and below ground components of the seedling. The shoot and root biomass ratio was significantly higher in holm oak seedlings from the smallest containers (Table 2). This can be attributed to the limited container space $\left(120 \mathrm{~cm}^{3}\right)$, which disturbs the balance of the $S: R$, probably due to strong root deformation, since the root deformation inhibits root development, and the development of above-ground parts as well. Topić et al. (23) showed that the cultivation of holm oak seedlings in a container volume of $120 \mathrm{~cm}^{3}$ must be shorter than one vegetation period, due to the strong deformation of the root system. The influence of the container size and depth on the seedlings' quality is presented with Dickson's qualitative index, which is a very good indicator of the seedlings' quality, since it serves as an assessment of morphological parameters (height, diameter and biomass), which are interconnected in a complex relation (21). The results show that the quality (according to the DQI) of

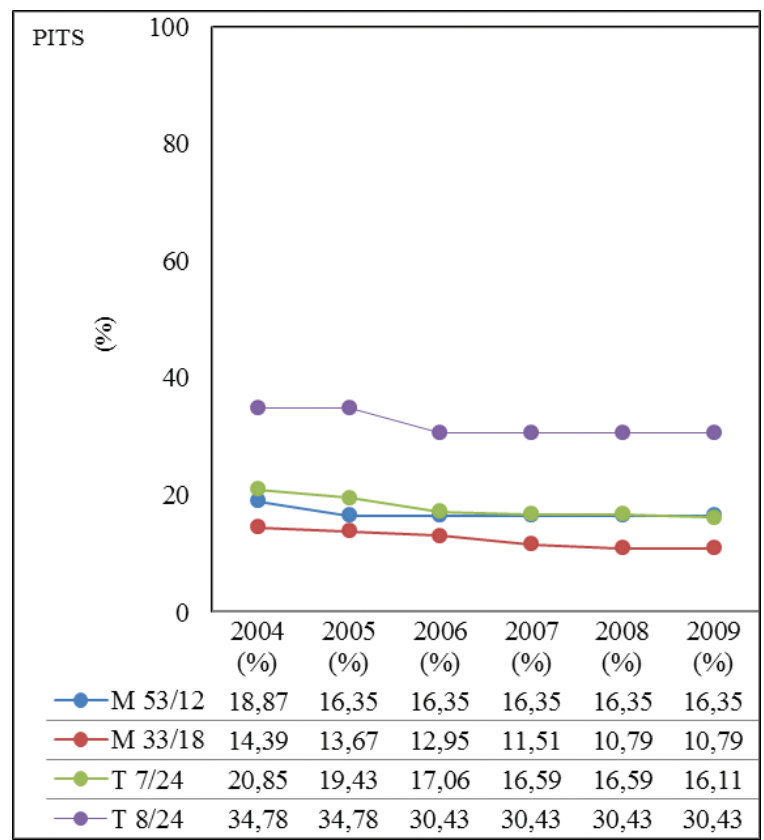

Figure 5 Holm oak's (Quercus ilex) survival after 6 years, planted in pits, different container types

seedlings produced in LC $\left(923\right.$ and $\left.1024 \mathrm{~cm}^{3}\right)$ was significantly higher and confirmed the evident influence of the container size on the seedling quality (Table 2).

\section{The survival of one year old holm oak seedlings in the field experiment for period 2004-2009}

This part presents the survival results of the holm oak, grown in different container types and planted in the ground where the soil was prepared in two ways: as manually excavated pits and by ripping. The results are shown for each year of the six year period (2004 - 2009). At the end of the first vegetation period, considering all types of containers and the method of soil preparation, the survival rate of holm oak ranged from 13,38\% (from containers $\mathrm{MP}_{53 / 12}$ planted in the ripped ground) to $71,05 \%$ (from containers $\mathrm{T}_{8 / 24}$ planted in the ripped ground). The results show twice as high survival rate on the ripped ground, compared to the unprepared soil where plants were planted in pits $40 \times 40 \times 40 \mathrm{~cm}$, when considering only larger containers (Figures 4 and 5). Unfortunately, due to technical issues, seedlings from containers $\mathrm{MP}_{33 / 18}$ were not planted in the ripped ground. To eliminate that deficiency, the average survival rate of holm oak from two smaller containers, and the average survival rate of holm oak in the field experiment from two large containers were used, separately for each soil preparation method. The survival results of holm oak from small volume containers (SC) include the average survival results from the containers $\mathrm{MP}_{53 / 12}$ and $\mathrm{MP}_{33 / 18}$, and the survival results of holm oak from large volume containers (LC) include the survival 
Table 3. The results of survival analysis of holm oak (Quercus ilex) presented by logistic regression coefficients with the level of significance for the initial height (2003.), soil preparation and container size

\begin{tabular}{|lcccccc}
\hline Variable & $\beta$ & S.P. & Wald Chi-Square & $\mathrm{p}$ & $\exp (\beta)=\operatorname{odd}$ ratio \\
\hline Intercept & -1.7958 & 0.3189 & 31.7027 & $<0.0001$ & \\
Height 2003. & -0.00349 & 0.0238 & 0.0214 & 0.8836 & 0.9965 \\
Soil preparation (ripping) & -0.2330 & 0.3160 & 0.5440 & 0.4608 & 0.7922 \\
Container size (LC) & 0.3021 & 0.2635 & 1.3147 & 0.2516 & 1.3515 \\
\hline Soil preparation (ripping) $\times$ Container size (LC) & 1.884 & 0.4132 & 20.7878 & $<0.0001$ & 6.5798 \\
\hline
\end{tabular}

Table 4 Average height growth of holm oak (Quercus ilex), according to the container type and soil preparation method for the period of $2003-2009$

\begin{tabular}{|c|c|c|c|c|c|c|c|c|c|}
\hline \multicolumn{10}{|c|}{ Quercus ilex (L.) } \\
\hline \multirow{2}{*}{\multicolumn{2}{|c|}{\begin{tabular}{|l|} 
Container type \\
Soil preparation
\end{tabular}}} & \multicolumn{2}{|c|}{$\mathrm{MP}_{53 / 12}$} & \multicolumn{2}{|c|}{$\mathrm{MP}_{33 / 18}$} & \multicolumn{2}{|c|}{$\mathrm{T}_{7 / 24}$} & \multicolumn{2}{|c|}{$\mathrm{T}_{8 / 24}$} \\
\hline & & ripped & pits & ripped & pits & ripped & pits & ripped & pits \\
\hline \multirow{7}{*}{$\begin{array}{l}\text { Vegetation } \\
\text { period }\end{array}$} & 2003-2004 & $+7.6 \mathrm{~cm}$ & $+5.6 \mathrm{~cm}$ & & $+5.2 \mathrm{~cm}$ & $+5.3 \mathrm{~cm}$ & $+1.9 \mathrm{~cm}$ & $+6.4 \mathrm{~cm}$ & $+3.9 \mathrm{~cm}$ \\
\hline & 2004-2005 & $+5.4 \mathrm{~cm}$ & $+4.2 \mathrm{~cm}$ & & $+4.3 \mathrm{~cm}$ & $+6.6 \mathrm{~cm}$ & $+4.8 \mathrm{~cm}$ & $+6.6 \mathrm{~cm}$ & $+6.0 \mathrm{~cm}$ \\
\hline & $2005-2006$ & $+4.0 \mathrm{~cm}$ & $+2.4 \mathrm{~cm}$ & & $+3.7 \mathrm{~cm}$ & $+4.1 \mathrm{~cm}$ & $+5.7 \mathrm{~cm}$ & $+4.9 \mathrm{~cm}$ & $+4.2 \mathrm{~cm}$ \\
\hline & $2006-2007$ & $+4.6 \mathrm{~cm}$ & $+3.7 \mathrm{~cm}$ & & $+3.7 \mathrm{~cm}$ & $+6.2 \mathrm{~cm}$ & $+9.7 \mathrm{~cm}$ & $+5.6 \mathrm{~cm}$ & $+6.9 \mathrm{~cm}$ \\
\hline & $2007-2008$ & $+4.1 \mathrm{~cm}$ & $+4.7 \mathrm{~cm}$ & & $+5.6 \mathrm{~cm}$ & $+8.6 \mathrm{~cm}$ & $+7.2 \mathrm{~cm}$ & $+7.8 \mathrm{~cm}$ & $+8.9 \mathrm{~cm}$ \\
\hline & 2008-2009 & $+3.1 \mathrm{~cm}$ & $+4.5 \mathrm{~cm}$ & & $+4.7 \mathrm{~cm}$ & $+12.2 \mathrm{~cm}$ & $+12.0 \mathrm{~cm}$ & $+12.3 \mathrm{~cm}$ & $+10.7 \mathrm{~cm}$ \\
\hline & $\Sigma$ & $28.8 \mathrm{~cm}$ & $25.1 \mathrm{~cm}$ & no data & $27.2 \mathrm{~cm}$ & $43 \mathrm{~cm}$ & $41.3 \mathrm{~cm}$ & $43.6 \mathrm{~cm}$ & $40.6 \mathrm{~cm}$ \\
\hline
\end{tabular}

results from containers $\mathrm{T}_{7 / 24}$ and $\mathrm{T}_{8 / 24}$. The fact that the $\mathrm{MP}_{53 / 12}$ and $\mathrm{MP}_{33 / 18}$ containers are of relatively approximate size and are much smaller compared to $\mathrm{T}_{7 / 24}$ and $\mathrm{T}_{8 / 24}$ containers, which are of the approximate size, supported the justification of this methodological approach for analyzing and presenting the results. Furthermore, the results of holm oak seedlings' quantitative morphological features were in general not significantly different within two smaller $\left(\mathrm{MP}_{53 / 12}\right.$ and $\left.\mathrm{MP}_{33 / 18}\right)$ and within two large containers $\left(\mathrm{T}_{7 / 24}\right.$ and $\left.\mathrm{T}_{8 / 24}\right)$, as shown in the previous section. Statistically significant logistic regression model (likelihood ratio $(\mathrm{LR})=68.7592$, $\mathrm{p}<0.0001$ ) was applied to analyze holm oak mortality in the field experiment (Table 3). The logistic regression model included four variables: the initial height of holm oak after planting, soil preparation, container size, and the interaction: soil preparation $\times$ container size. Interaction: - soil preparation $-x$ - container size was the only variable that affected the survival rate of holm oak plants six years after planting. The combination: ripped ground $\times$ large containers $(923$ and $1024 \mathrm{~cm}^{3}$ ) provided a 6.5 times greater survival rate chance, compared to the combination: pits $-x$ - smaller containers $\left(120\right.$ and $\left.220 \mathrm{~cm}^{3}\right)$. The presented results are in accordance with the results of Palacios et al. (15), who established a 12 times greater survival chance by planting holm oak high-quality seedlings in the ripped ground, compared to low-quality seedlings planted in the pits excavated manually. Also, slightly better survival rate
(23.27\%) was determined for the seedlings cultivated in larger containers (LC) and planted in pits excavated manually. In this case, also, the effect of the large container (LC) on the survival rate came to expression. The explanation for this could be found in the work of Tsakaldimi et al. (26), who obtained higher specific root length (SRL) for seedlings cultivated in containers of larger volume, and Pemán (16), who obtained higher SRL in deeper containers. The higher SRL implies thinner roots (less resistance to radial flow in these roots compared to denser or thicker roots) and thus a better utilization of water and nutrients from the soil, due to the higher hydraulic conductivity (12). The seedlings from deeper containers $\left(T_{7 / 24}\right.$ and $\mathrm{T}_{8 / 24}$ ) had substantially longer tap roots, compared to the seedlings from smaller and shallower containers (data not shown), which are, according to the Peñuelas \& Ocaña (17), limited by container depth. Dominguez-Lerena et al. (6) found that the holm oak survival linearly increases with the container depth. The larger root volume, larger surface area and greater total root length, which was the case we had with seedlings produced in LC, quite possibly contributed to greater water and mineral-nutrient consumption in the early development stage, which is extremely important in the dry summer period, when the survival and growth were restricted by low water availability. Villar - Salvador et al. (27) noticed that plants with a higher aboveground part had significantly lower mortality. Seedlings with larger diameter, planted in a field ex- 
Vertical bars denote 0,95 confidence intervals

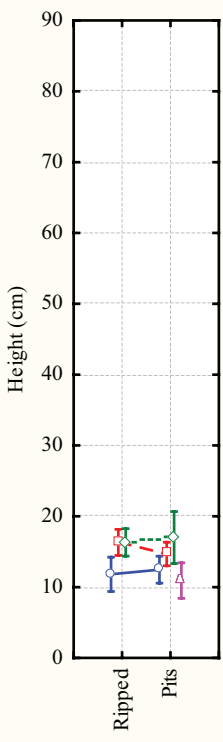

2003.

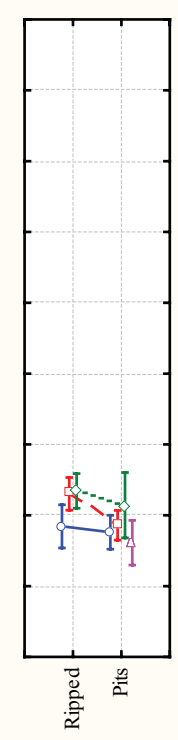

2004 .

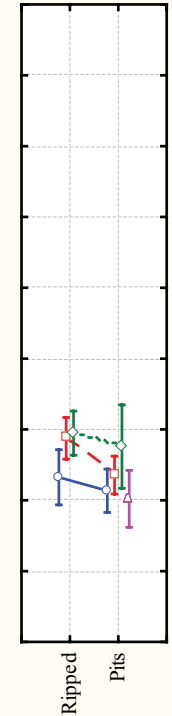

2005

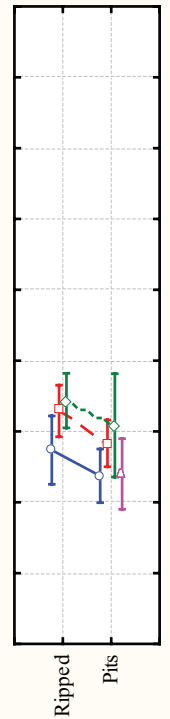

2006.



2007.

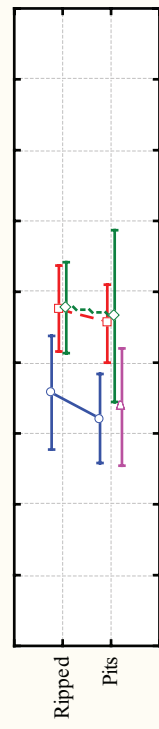

2008 .

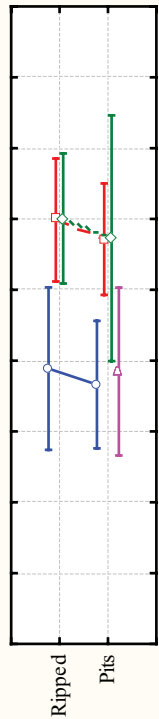

2009.

Figure 6 Height increment of holm oak (Quercus ilex) according to the container type and soil preparation for the period of 2003-2009

periment, had significantly lower mortality (26). Our results show that plants with such morphological features can be produced only in larger containers. Even seedlings from larger containers, with proven higher quality level, did not have a satisfactory survival result when planted in pits. The responsibility for this could be found in soil preparation, which is particularly evident in the case of planting quality seedlings (from LC) in ripped soil, where we registered significantly higher survival rate in the first six years.

\section{The impact of the container size and soil preparation on holm oak's height increment on the field}

Holm oak's height increment for the period from 2003 to 2009 is shown in Figure 6. Holm oak plants from the $\mathrm{T}_{7 / 24}$ containers, planted in the ripped ground, had an average height of $59.86 \pm 8.33^{*} \mathrm{~cm}$ at the end of the sixth vegetation season. Plants from the $\mathrm{T}_{8 / 24}$ containers, planted in the ripped ground, had the highest average height of $60.08 \pm 9.02^{*} \mathrm{~cm}$. Plants of holm oak from the $\mathrm{MP}_{53 / 12}$ containers, planted in the ripped ground, had an average height of $38.88 \pm 10.85^{*} \mathrm{~cm}$, and the smallest were the plants from the $\mathrm{MP}_{53 / 12}$ containers, planted in the pits with a height of $36.62 \pm 6,55^{*} \mathrm{~cm}$. Plants from the $\mathrm{MP}_{33 / 18}$ containers, planted in manually excavated pits, had an average height of $38.47 \pm 10.62^{*} \mathrm{~cm}$. Table 4 shows that the annual height increment between plants from the

*0.95 confidence interval same type of containers planted in the soil with two different soil preparation methods is quite similar. However, a difference in height increment of the plants from different container sizes, regardless of the soil preparation method, can be observed. Plants from LC reached significantly greater height compared to those from SC during the first six years. Soil preparation method did not affect the height increment but it is evident that the container size had an influence on height increment of holm oak trees for the period from 2003 to 2009 (Table 5). To demonstrate the container type impact on height increment of holm oak trees, only seedlings planted in pits were considered (Figure 7), due to a lack of plants from containers $\mathrm{MP}_{33 / 18}$ planted in the ripped ground. The container size exhibited influence on height increment in the first 6 years: there was a statistically significant difference between the containers $(\mathrm{F}=9.410, \mathrm{p}=0.000010)$ and, according to post-hoc Tukey's test, between the two smaller $\left(\mathrm{MP}_{53 / 12}\right.$ and $\left.\mathrm{MP}_{33 / 18}\right)$ and two large containers $\left(\mathrm{T}_{7 / 24}\right.$ and $\mathrm{T}_{8 / 24}$. The height increment of holm oak trees was significantly affected only by the container size, as opposed to the survival which was influenced by the interaction: soil preparation - container size. The results clearly showed that the seedlings from LC were significantly higher than those in SC, taking into account only ripped ground at the experimental site. This was probably a result of very strong root deformation or circular and rebound tap root growth of seedlings cultivated in containers of small volume and depth $\left(\mathrm{MP}_{53 / 12}\right.$ and $\left.\mathrm{MP}_{33 / 18}\right)$. The larger and deeper containers produced healthier and high-quality seedlings with well-developed root systems (23). These plants had a much higher potential for deep 
Table 5. Repeated Measures ANOVA for the impact of the container size and preparation method on Quercus ilex L. height growth

\begin{tabular}{|c|c|c|c|c|c|}
\hline \multirow[t]{2}{*}{ Effect } & \multicolumn{5}{|c|}{$\begin{array}{c}\text { Repeated Measures Analysis of Variance (QUERCUS PM) } \\
\text { Sigma-restricted parameterization } \\
\text { Effective hypothesis decomposition }\end{array}$} \\
\hline & SS & Degr. of Freedom & MS & $\mathrm{F}$ & $\mathrm{p}$ \\
\hline Intercept & 768429.7 & 1 & 768429.7 & 1034.706 & 0.000000 \\
\hline Container size & 15313.0 & 1 & 15313.0 & 20.619 & 0.000012 \\
\hline Preparation method & 1514.1 & 1 & 1514.1 & 2.039 & 0.155453 \\
\hline Container size x Preparation method & 32.9 & 1 & 32.9 & 0.044 & 0.833463 \\
\hline Error & 109170.3 & 147 & 742.7 & & \\
\hline Year & 107332.2 & 6 & 17888.7 & 255.535 & 0.000000 \\
\hline Year x Container size & 7101.0 & 6 & 1183.5 & 16.906 & 0.000000 \\
\hline Year x Preparation method & 239.1 & 6 & 39.9 & 0.569 & 0.755006 \\
\hline Year x Container size x Preparation method & 175.2 & 6 & 29.2 & 0.417 & 0.867987 \\
\hline Error & 61744.3 & 882 & 70.0 & & \\
\hline
\end{tabular}

Numbers in a row followed by the same letter are not significantly different according to Tukey's test $(p=0,05)$

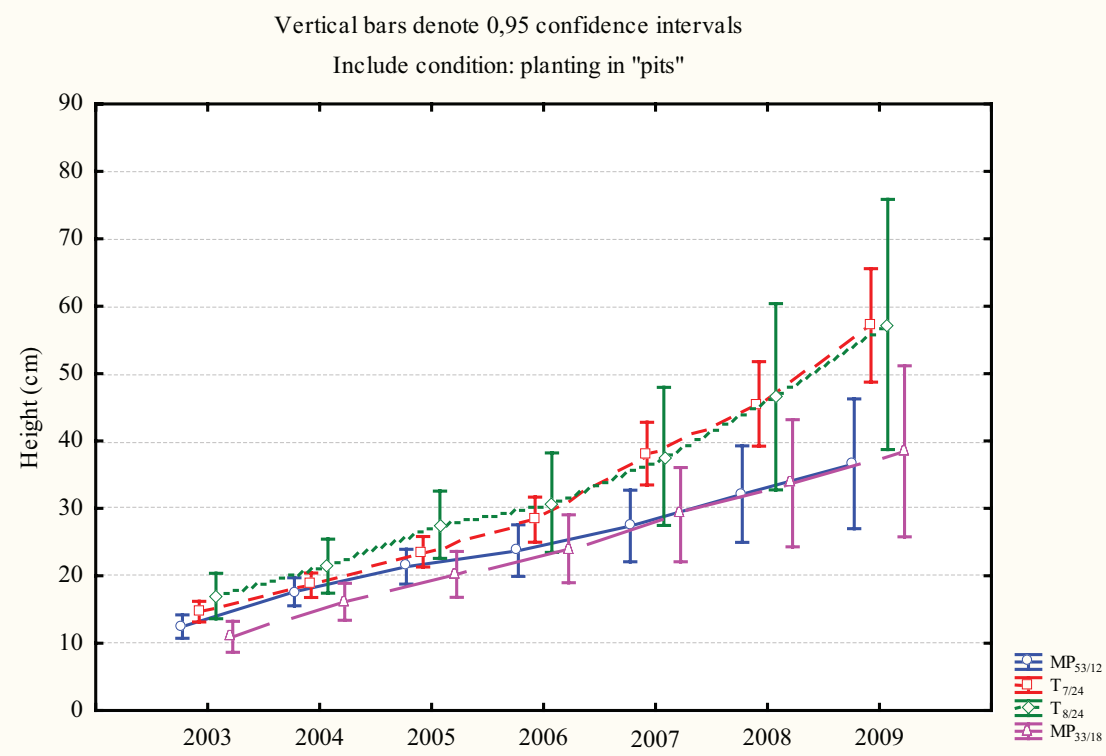

Figure 7 Height increment of holm oak (Quercus ilex) in different container types planted in pits

rooting and rapid penetration into the deeper soil layers, where there is more moisture necessary for their growth and development, especially in the arid summer months, unlike the low-quality seedlings (from smaller containers). Topić et al. (25) also noticed better height increment of common cypress plants when grown in larger containers. This research fully agrees with the research of Chirino et al. (3), which in the case of cork oak concluded that it is necessary to cultivate oak seedlings in deeper containers (of depth of at least $19 \mathrm{~cm}$ ). Higher seedling quality (seedlings from the LC) came to expression in the ripped ground. In addition to the container depth and size, a prerequisite that must be fulfilled in order to achieve increased seedling height increment, certainly is a procedure that improves water - air regime in the soil. In the dry karst and shallow soil conditions of Mediterranean this can be achieved with a deeper mechanical tillage (by ripping). On the ripped ground, the root systems of the seedlings rapidly penetrate into the deeper soil horizons, which causes faster height increment (22). Deep rooting is enabled by tap root and abundant root system of seedlings; this can be produced only in containers of larger volume and depth. The mechanical soil preparation also contributes to this by shredding stone in the soil. 


\section{CONCLUSIONS}

1. All morphological features of holm oak seedlings showed significantly higher values in larger containers $\left(\mathrm{T}_{7 / 24}\right.$ and $\left.\mathrm{T}_{8 / 24}\right)$ compared to smaller containers $\left(\mathrm{MP}_{53 / 12}\right.$ and $\left.\mathrm{MP}_{33 / 18}\right)$. Different container types exhibited different impacts on the root system quality. One year old holm oak seedlings easily develop proper lateral roots in larger containers. The seedlings of one year old holm oak cultivated in container $\mathrm{MP}_{53 / 12}$ developed highly deformed root systems due to the inadequate dimensions. Deformations in the larger containers were not noticed, which makes these seedlings of higher quality.

2. Soil preparation by ripping combined with highquality seedlings (the seedlings from larger containers) played the most important role on the holm oak survival in the first six years after planting.

3. The container size was the important variable that can account for better height increment of holm oak in a field experiment, while soil preparation had no significant impact.

\section{REFERENCES}

1. BERNIER P Y, LAMHAMEDI M S, SIMPSON D G, 1995 Shoot:Root Ratio Is of Limited Use in Evaluating the Quality of Container Conifer Stock. Tree Planters' Notes - Volumes 46: Number 3.

2. BOCIO I, NAVARRO F B, RIPOLL M A, JIMENEZ M N, DE SIMON E 2004 Holm oak (Quercus rotundifolia Lam.) and Aleppo pine (Pinus halepensis Mill.) response to different soil preparation techniques applied to forestation in abandoned farmland. Ann. For. Sci. 61: 171-178

3. CHIRINO E, VILAGROSA A, HERNANDEZ E I, MATOS A, VALLEJO V R 2008 Effects of a deep container on morpho-functional characteristics and root colonization in Quercus suber L. Seedlings for reforestation in Mediterranenan climate. Forest Ecology and Management 256: 779-785

4. DAVIS C S, 2002 Statistical Methods for the Analysis of Repeated Measurements, Springer, New York

5. DOMÍNGUEZ-LERENAS, HERRERO SIERRAN, CARRASCO MANZANO I, OCAÑA BUENO L, PEÑUELAS RUBIRA J L 1997 Ensayo de diferentes tipos de contendores para Quercus ilex, Pinus halepensis, Pinus pinaster y Pinus pinea: resultados de vivero. Actas del II Congreso Forestal Espanol. Pamplona. Mesa 3: 189-194

6. DOMÍGUEZ-LERENA, S, CARASCO MANZANO I, HERRERO SIERRA N, OCAÑA BUENO L, PERAGÓN J L N, PEÑUELAS RUBIRA, J L 2000 Las características de los contenedores influyen en la supervivencia y crecimiento de las plantas de Pinus pinea en campo. Actas del $1^{\text {er }}$ Simposio sobre el pino pinońero. Valladolid. Volumen 1: 203-209

7. DOMÍNGUEZ-LERENAS, HERRERO SIERRAN, CARRASCO MANZANO I, OCAÑA BUENO L, PEÑUELAS RUBIRA J L, MEXAL J G 2006 Container characteristics influence Pinus pinea seedling development. Forest Ecology and Management 221: 63-71 http://dx.doi.org/10.1016/j.foreco.2005.08.031

8. HARRIS R W 1992 Root-Shoot Ratios. Journal of Arboriculture 18 (1): $39-42$
9. JELIĆ G, TOPIĆ V, BUTORAC L, ĐURĐEVIĆ Z, JAZBEC A, ORŠANIĆ, M 2014 Utjecaj veličine kontejnera i pripreme tla na uspjeh pošumljavanja jednogodišnjim sadnicama bora pinije (Pinus pinea L.) na sredozemnom području Republike Hrvatske. Šumarski list 9-10: 463-475

10. LANDIS T D 1990 Containers: types and functions, Landis T D, Tinus R W, McDonald S E and J P Barnett 1990 Containers and growing media, Vol. 2, The container Tree Nursery Manual. USDA For. Serv., Washington, D. C.; Agric. Handbook 1 - 39

11. MATIĆ S, PRPIĆ B 1983 Pošumljavanje. Zagreb

12. NICOTRAA B, BABICKA N, WESTBOY M 2002 Seedling root anatomy and morphology: an examination of ecological differentiation with rainfall using phylogenetically independent contrasts. Oecologia 130: 136-145

13. OCVIREK M 1997 Utjecaj termina sjetve na razvijenost biljaka hrasta lužnjaka (Quercus robur L.) u trima tipovima kontejnera. Radovi šumarskog instituta Jastrebarsko 32 (2): 55-72.

14. PALACIOS G, NAVARRO CERRILO R M 2008 Effecto de la calidad de planta, el procedimiento de preparacion y la fecha de la plantacion en la supervivencia de una repoblacion de Pinus pinea L. Cuad. Soc. Esp. Cien. For. 17: 199-204

15. PALACIOS G, NAVARRO CERRILO R M, CAMPO A, TORAL M 2009 Site preparation, stock quality and planting date effect on early establishment of Holm oak (Quercus ilex L.) seedlings. Ecological Engineering 35: 38-46

16. PEMÁN J, VOLTAS J, GIL-PELEGRIN E 2006 Morphological and functional variability in the root system of Quercus ilex L. subject to confinement: consequences for afforestation. Ann. For. Sci. 63: 425-430 http://dx.doi.org/10.1051/forest:2006022

17. PEÑUELAS J L, OCAÑA L 1996 Cultivo de plantas forestales en contenedor. Ministerio de Agricultura, Pesca y Alimentacion, Mundi-Prensa, Madrid, ISBN: 84-7114-644-4: pp. 190

18. SOKAL R R, ROHLF F J 1995 Biometry. Freeman and Company. New York

19. SOUTH D B, ROSE R W, MCNABB K L 2001 Nursery and site preparation interaction research in the United States. New Forests 22: 43-58 http://dx.doi.org/10.1023/A:1012079014625

20. SUTTON R E 1993 Mounding site preparation: a rewiew of Europaean and North American experience. New Forests 7: 151-192 http://dx.doi.org/10.1007/BF00034198

21. THOMPSON B E, 1986 Seedling morphological evaluation: what you can tell by looking. In: DURYEA M L (ed.), Evaluating Seedling quality: Principles, Procedures and Predictive Ability of Major Tests. Oregon State University, Corvallis, OR. pp 59-71

22. TOMAŠEVIĆ A 1994 Podrivanje kao prva faza pripreme tla za pošumljavanje. Šumarski list 5-6: 173-181

23. TOPIĆ V, BUTORAC L, JELIĆ G, PERIĆ S 2006 Influence of container type on growth and development of holm oak (Quercus ilex $L$.) seedlings in a nursery. Periodicum biologorum, vol. 108, No 6, 643-648

24. TOPIĆ V, ĐURĐEVIĆ Z, BUTORAC L, JELIĆ G 2006a Utjecaj tipa kontejnera na rast i razvoj sadnica pinije (Pinus pinea L.) u rasadniku. Rad. šumar. inst., Izvanredno izdanje 9: 149-157

25. TOPIĆ V, BUTORAC L, ĐURĐEVIĆ Z, KEKELIĆ B, JELIĆ G 2009 Utjecaj tipa kontejnera na rast i razvoj sadnica običnog čempresa (Cupressuss sempervirens var. pyramidalis Nyman.) u rasadniku i šumskoj kulturi. Šumarski list 3-4: 121-134

26. TSAKALDIMI M, ZAGAS T, TSITSONI T, GANATSAS P 2005 Root morphology, stem growth and field performance of seedlings of two Mediterranean evergreen oaks species raised in different container types. Plant Soil 278: 85-93 http://dx.doi.org/10.1007/s11104-005-2580-1

27. VILLAR-SALVADOR P, PLANELLES R, ENRÍQUEZ E, PENUUELAS RUBIRA J 2004 Nursery cultivation regimes, plant 
functional attributes, and field performance relationships in the Mediterranenan oak Quercus ilex L. Forest Ecology and Management 196: 257-266 http://dx.doi.org/10.1016/j.foreco.2004.02.061

28. (Electronic Version): StatSoft, Inc. (2011). Electronic Statistics Textbook. Tulsa, OK: StatSoft. WEB: http://www.statsoft.com/ textbook/.
29. SAS Institute Inc. Cary, NC, USA: SAS Online Doc; 2008: http://support.sas.com/documentation/onlinedoc/91pdf/index_913.html\#stat

30. http://eur-lex.europa.eu/legal-content/EN/TXT/ PDF/?uri=CELEX:31999L0105\&rid=2 